(C) 2021, The Authors. Published by Elsevier Inc. and Fass Inc. on behalf of the American Dairy Science Association ${ }^{\circledR}$. This is an open access article under the CC BY-NC-ND license (http://creativecommons.org/licenses/by-nc-nd/4.0/).

\title{
The effect of fertilizer nitrogen input to grass-clover swards and calving date on the productivity of pasture-based dairy production
}

\author{
K. M. Scully, ${ }^{1,2 *}$ B. Keogh, ${ }^{2} \odot$ B. O' Brien, ${ }^{1} \odot$ I. A. Casey, ${ }^{2} \odot$ and J. Humphreys ${ }^{1}$ \\ ${ }^{1}$ Teagasc, Animal \& Grassland Research and Innovation Centre, Moorepark, Co. Cork, P61 C997, Ireland \\ ${ }^{2}$ Department of Chemical and Life Sciences, Waterford Institute of Technology, Waterford, X91 KOEK, Ireland
}

\begin{abstract}
The objective of this systems-scale study was to investigate grazing season timeframes on pasture and milk production and on milk processability of dairy systems with compact spring-calving dairy cows grazing white clover (Trifolium repens L.) based grassland. Fifty-four primiparous and multiparous Holstein-Friesian dairy cows were used in a one-factor study with 3 systems $(\mathrm{n}=18)$ and repeated over 2 yr $(2008 / 09$ and 2009/10). The 3 systems were: early spring calving with annual fertilizer $\mathrm{N}$ input of $100 \mathrm{~kg} \cdot \mathrm{ha}^{-1}$ applied in spring (ES100N; 2.1 cows $^{-1} a^{-1}$; grazing February to November), early spring calving without fertilizer $\mathrm{N}$ (ES0N; 1.6 cows.ha ${ }^{-1}$; grazing February to November) and late spring calving without fertilizer N (LS0N; 1.53 cows.ha ${ }^{-1}$; grazing April to January). Annual pasture production was affected by an interaction between grazing system and year: Mean annual pasture yields for 2008 and 2009 were ES100N; 10.35 and 9.88, ES0N; 8.88 and 8.63 , LS0N; 9.18 and $10.31 \mathrm{t}$ of dry matter (DM) $\cdot$ ha $^{-1}$ (SEM 0.39). LSON had higher pasture DM yield in 2009 due to higher clover DM production and biological $\mathrm{N}$ fixation compared with the other systems. Clover stolon and root mass in the following February was correlated with stolon and root mass in the previous November with $64 \%$ of stolon mass present on LS0N in February $\left(\mathrm{R}^{2}=0.84\right)$. There were no detectable differences in per-lactation milk yield $(6,335$ $\left.\mathrm{kg} \cdot \mathrm{cow}^{-1}\right)$, fat, protein and lactose yields $(271,226$, $297 \mathrm{~kg} \cdot \mathrm{cow}^{-1}$, respectively), cow liveweight $(585 \mathrm{~kg}$ ) or body condition score (3.02). Although winter grazing favored subsequent clover DM production, biological N fixation and pasture DM production, delaying calving date in spring and extending lactation into the following winter led to inefficient use of this pasture by the grazing herd and lowered the quality of late-lactation milk for processing purposes. Hence, a mean calving
\end{abstract}

Received November 11, 2020.

Accepted April 5, 2021.

*Corresponding author: katie.scully@teagasc.ie date in mid- to late-February is recommended for zerofertilizer $\mathrm{N}$ input clover-based grassland.

Key words: dairy cow, white clover, nitrogen fertilizer, milk production, milk processability

\section{INTRODUCTION}

The environmental effects of mineral nitrogen are of global concern, and there is growing determination to mitigate its use for agricultural purposes (ECE, 2020). Within the European Union, the European Commission (EC) has recently launched the Farm to Fork Strategy as part of the European Green Deal to tackle climate and environmental-related challenges and targets a $20 \%$ reduction in fertilizer use by 2030 (EC, 2019). The replacement of synthetic fertilizer $\mathrm{N}$ with $\mathrm{N}$ fixed by bacteria (biological $\mathrm{N}$ fixation; BNF) in association with white clover (Trifolium repens L.) offers the potential to lower fertilizer $\mathrm{N}$ use, nitrous oxide and ammonia emissions and energy use. This in turn helps reduce the carbon footprint and other environmental effects of milk production (Li et al., 2011; Yan et al., 2013) while remaining economically competitive (Humphreys et al., 2017). These benefits are largely dependent on maintaining the clover component of the sward at agronomically desirable levels of approximately 300 $\mathrm{g} \cdot \mathrm{kg}^{-1}$ of pasture DM from year to year (Frame and Newbould, 1986).

The optimal temperatures for growth of white clover are higher than perennial ryegrass (Lolium perenne) and this makes clover vulnerable to competition by perennial ryegrass particularly during the winter and early spring (Davies, 1992). Previous plot-scale investigations by Laidlaw and Stewart (1987), Laidlaw et al. (1992) and Phelan et al. (2014) showed that carrying high covers of pasture for long periods over the winter and early spring was detrimental to white clover survival and, hence, the subsequent productivity of swards. Furthermore, the application of fertilizer N to grass-clover swards in spring to increase grass production can be detrimental to the white clover component of the sward (Laidlaw et al., 1992; Chapman et al., 
2017). Conversely, white clover tends to be prominent in the sward from mid-summer onwards (Frame and Newbould, 1986; Laidlaw et al., 1992; Enriquez-Hidalgo et al., 2018), with high levels of BNF, which provides the potential for higher pasture production to extend the grazing season into the late autumn and winter.

Rates of pasture growth are highly seasonal in temperate latitudes (Hurtado-Uria et al., 2013). The period when pasture growth meets the demand by grazing dairy cows is limited. In Western Europe pasture deficits due to low growth rates typically occur in late autumn, winter and early spring. Traditional pasturebased dairy systems are designed to match the herd demand for feed to the production of home-grown feed (grazed and ensiled pasture) with minimal purchased concentrate feed. A long grazing season and a short period of winter housing are key elements of low-cost pasture-based dairy production (Finneran et al., 2012; Hanrahan et al., 2018; Läpple et al., 2012). Hence, in Ireland, dairy cows are compactly calved with a mean calving date in February and are typically dried off and housed during the winter.

A key component of seasonal pasture-based milk production is matching calving date to the commencement of pasture growth in spring to produce as much milk as possible off low-cost grazed pasture during the grazing season. Hence, in the absence of applications of fertilizer $\mathrm{N}$ in spring, and consequently lower pasture production in spring, a later calving date might better align pasture supply with the requirement for feed by the spring-calving herd. Under such a management strategy producing milk off pasture can be maintained by extending the grazing season into the following winter. In some instances there is a premium price paid for milk produced during the winter months. Nevertheless, the composition of milk changes during lactation (Lucey, 1996) and milk produced by later calving cows with a later turnout date in spring is likely to reflect lactational and nutritional influences in late lactation (O'Brien et al., 1999). This is likely to have consequences for the yield, composition and quality of milk products (Lucey, 1996; O'Brien et al., 2006; Fox et al., 2017).

The objective of this study was to examine a system of milk production with later than typical mean calving and turnout to pasture dates (mid-April) with the end of lactation in the following January compared with systems with conventional calving and turnout dates (mid-February) with the end of lactation in mid-November. Aspects examined include the productivity of white clover in grassland, BNF, and pasture and milk production as well as indicators of the processability of late-lactation milk.

\section{MATERIALS AND METHODS}

\section{Site Characteristics and Meteorological Data}

The study was conducted at Solohead Research Farm in Ireland $\left(52^{\circ} 51^{\prime} \mathrm{N}, 08^{\circ} 21^{\prime} \mathrm{W}\right.$; $95 \mathrm{~m}$ above sea level) between February 2008 and February 2010. The soils of the farm are $90 \%$ poorly drained gleys and $10 \%$ grey-brown podzolics overlaying Devonian sandstone at a depth of 5 to $10 \mathrm{~m}$ below ground level. The soil has a clayloam texture, comprising $36 \%$ sand and $28 \%$ clay in the A1 horizon. Soil organic matter content was $13 \%$, and soil $\mathrm{pH}$ was 6.6. The land has been under permanent grassland for more than 50 years and was reseeded with perennial ryegrass (Lolium perenne) between 1985 and 1995. Between 2001 and 2006, the grassland sward was oversown with white clover as described by Humphreys et al. (2009). The botanical composition of the swards in September 2008 (in $\mathrm{g} \cdot \mathrm{kg}^{-1}$ of pasture DM) was predominantly perennial ryegrass (approximately 750 $\mathrm{g} \cdot \mathrm{kg}^{-1}$ ) and white clover (approximately $200 \mathrm{~g} \cdot \mathrm{kg}^{-1}$ ). Unsown species were primarily dandelion (Taraxacum officinale), creeping buttercup (Ranunculus repens), daisy (Bellis perennis) and ribwort plantain (Plantago lanceolata), which in total accounted for less than 50 $\mathrm{g} \cdot \mathrm{kg}^{-1}$.

Soil temperature $\left({ }^{\circ} \mathrm{C}\right.$ at $10 \mathrm{~cm}$ depth) and rainfall $(\mathrm{mm})$ were measured every $30 \mathrm{~min}$ at an automatic meteorological station on the farm (Campbell Scientific Ltd.).

\section{Experimental Design and Grazing Systems}

Fifty-four (12 primiparous and 42 multiparous) Holstein-Friesian spring-calving dairy cows were used in a one-factor study with 3 grazing systems and 18 cows per system per year (from February to February), repeated over 2 years. At the end of lactation, all cows were housed together and fed together as one group. Each spring all cows were divided into 4 main groups on the basis of lactation number $(1,2,3$, and $\geq 4)$ and then subdivided into subgroups of 3 on the basis of calving date. From within each subgroup, one cow was randomly assigned to each herd. Herds were then randomly assigned to the 3 following systems:

- ES100N: Early spring turnout with an annual N fertilizer input of $100 \mathrm{~kg} \cdot \mathrm{ha}^{-1}$. This grazing system was typical of that recommended for conventional dairy production from cows grazing grass-clover swards in Ireland (Humphreys et al., 2009). The mean calving date was February 17 in each year, and lactating cows were primarily at pasture from 
February 21, 2008, to November 12, 2008, and from February 20, 2009, to November 18, 2009 (Table 1). Overall annual stocking rate was 2.1 cows $\cdot h^{-1}$ (Table 1).

- ES0N: Early spring turnout without fertilizer $\mathrm{N}$ input. Mean calving date, turnout dates, and housing dates were similar to ES100N (Table 1), but the overall annual stocking rate was 1.6 cows $\cdot \mathrm{ha}^{-1}$ as recommended by Culleton and Fox (2001).

- LSON: Late spring turnout without fertilizer N input. This system had a later mean calving date (April 12) to account for the lower supply of pasture in early spring that occurs in the absence of fertilizer $\mathrm{N}$ applications. Cows were primarily at pasture from April 16, 2008, to January 14, 2009, and from April 15, 2009, to January 26, 2010 (Table 1). The overall stocking rate was $1.7 \mathrm{cows} \cdot \mathrm{ha}^{-1}$ between April and September. However, this was reduced to 1.3 cows $\cdot$ ha $^{-1}$ between September to January by including additional land (3.7 ha) in this system. This simulated the housing of calves and heifers off the main grazing block for the winter.
A total of 34 ha of permanent grassland in both 2008 and 2009 was used for the study. The study area was divided into 6 blocks according to soil type and drainage status in January 2008, with each block containing 3 paddocks. One paddock from each block was randomly assigned to each grazing system, and paddock sizes were adjusted to achieve the land areas that determined the stocking rates (Table 1). Mean paddock sizes were 1.42, 1.88 , and $1.76 \mathrm{ha}^{-1}(\mathrm{SD}=0.30)$ in the ES100N, ES0N, and LSON, respectively. However, immediate stocking rates within each system changed over time as surplus pasture was removed for silage production (Table 1).

\section{Animal and Grazing Management}

Dairy cows were turned out to pasture $3 \mathrm{~d}$ after calving in spring and remained outside until drying off at the end of lactation in the following winter. Exceptions were made when ground conditions were too wet (soil moisture content $>60 \%$ ) or when pasture supply was insufficient at pregrazing pasture masses $<500 \mathrm{~kg}$ of $\mathrm{DM} \cdot \mathrm{ha}^{-1}$. Pasture was allocated for a 48 -h period to dairy cows under rotational strip-grazing management, and each herd was moved to the next pasture area when

Table 1. Details of the 3 clover-based grazing systems ${ }^{1}$ in 2008 and 2009

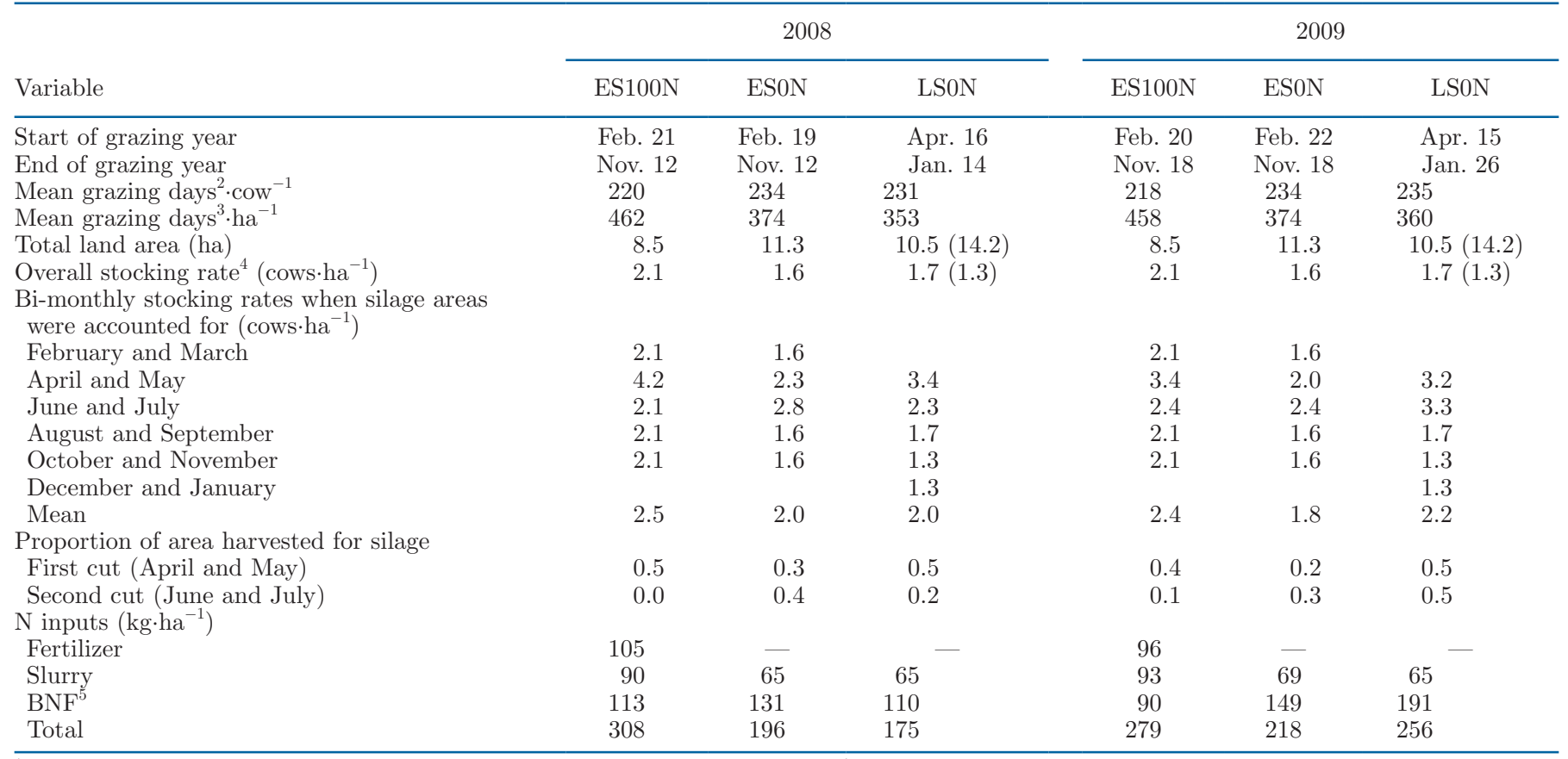

${ }^{1} \mathrm{ES} 100 \mathrm{~N}=$ early spring calving with annual fertilizer $\mathrm{N}$ input of $100 \mathrm{~kg} \cdot \mathrm{ha}^{-1}$ applied in spring; ES0N = early spring calving without fertilizer $\mathrm{N} ; \mathrm{LS} 0 \mathrm{~N}=$ late spring calving without fertilizer $\mathrm{N}$.

${ }^{2} 24$-h periods; a value of 0.5 was used when cows were kept indoors at night.

${ }^{3}$ The number of dairy cow grazing days per ha averaged over the entire area of each system.

${ }^{4}$ From September to January each year, additional land was included in the LSON system (adjusted land area and stocking rate are in parentheses). During the rest of the year, this area was used for grazing heifers and calves.

${ }^{5} \mathrm{BNF}=$ biological nitrogen fixation. 
a postgrazing height (PGH) of $5 \mathrm{~cm}$ was reached. The PGH was measured twice per day with 50 measurements of a Filips rising plate meter (Grasstec Agri Services). Back-fencing was used to stop cows returning to previously grazed areas. Excess pasture production was identified throughout the study and removed as baled silage. These areas were selected when pregrazing masses exceeded 1,600 $\mathrm{kg}$ of $\mathrm{DM} \cdot \mathrm{ha}^{-1}$ between April and July and $>2,000 \mathrm{~kg}$ of DM.ha ${ }^{-1}$ in August (above PGH of $5 \mathrm{~cm}$ ). Silage areas were closed off between early April and late May (first-cut silage) and between early June and mid-July (second-cut silage; Table 1). The land area available for grazing in each system at various times of the year and associated stocking rates are outlined in Table 1.

The ES100N system received annual mineral $\mathrm{N}$ fertilizer input of $100 \mathrm{~kg} \cdot \mathrm{ha}^{-1}$. Nitrogen fertilizer was applied as urea between February and April for early grazing and as calcium ammonium nitrate during May of each year. Slurry produced during housing was collected in a common store and reapplied to grassland on a proportional basis to stocking rate on each system (see Table 1) as described by Humphreys et al. (2008).

\section{Concentrates and Silage Fed}

Cows received concentrate feed supplementation ( $26 \%$ barley, $26 \%$ maize gluten, $35 \%$ beet pulp, and $12 \%$ soybean meal) at rates of between 3 and $5 \mathrm{~kg} \cdot \mathrm{cow}^{-1}$ between February and April and 0 and $4 \mathrm{~kg} \cdot \mathrm{cow}^{-1}$ between April to November for cows on ES100N and ES0N. Cows on LSON received between 4 and $5 \mathrm{~kg} \cdot \mathrm{cow}^{-1}$ from September through to drying off in late January. Rates of supplementation were dependent on pasture availability and nutritive value (see results). When housed, cows were fed grass-clover silage ad libitum.

\section{Sward Measurements}

Pasture Production and Nutritive Value. Pasture DM production was measured before each grazing event by cutting 4 random strips (each $5 \times 0.55 \mathrm{~m}$ ) using an HRH-536 lawn-mower (Honda) at a cutting height of $5 \mathrm{~cm}$ above ground level. Before harvesting grass-clover for silage, an Agria auto-scythe (Etesia UK Ltd.) was used to cut 3 strips $(5.0 \times 1.1 \mathrm{~m})$. All the harvested pasture samples were bulked and weighed, and a 100-g subsample was dried for $16 \mathrm{~h}$ in a forceddraft oven at $95^{\circ} \mathrm{C}$ to determine DM content. Annual pasture yield $\left(\mathrm{kg}\right.$ of DM$\left.\cdot \mathrm{ha}^{-1}\right)$ was calculated as the sum of pasture removed as pregrazing and presilage cuts. Growth rates for each pregrazing and presilage cut were calculated by dividing the pasture mass by the regrowth interval. A second 100-g subsample of composite pasture was freeze-dried and milled through a $0.2-\mathrm{mm}$ sieve before chemical analyses for ash content $\left(550^{\circ} \mathrm{C}\right.$ muffle furnace for $\left.12 \mathrm{~h}\right), \mathrm{CP}(\mathrm{N}$ content $\times 6.25$; Leco $\mathrm{N}$ analyzer FP-528, Leco Corp.), and in vitro organic matter digestibility (IVOMD) as described by Morgan et al. (1989). Silage grab samples of approximately $100 \mathrm{~g}$ were randomly collected $(\mathrm{n}=88)$ before feeding to housed animals throughout the study. This was analyzed for ash, IVOMD and CP using near infrared spectroscopy (Model 6500, Foss-NIR System). The NIR machine was calibrated on a monthly basis using 12 samples of varying nutritive value determined using laboratory techniques similar to that described above.

White Clover Content in Pasture DM, Biological Nitrogen Fixation, and Stolon and Root DM Mass. The white clover content of the pasture DM $\left(\mathrm{g} \cdot \mathrm{kg}^{-1}\right)$ in each paddock was measured from 30 randomly distributed strips (each $10 \times 30 \mathrm{~cm}$ ) of pasture sampled at a cutting height of $5 \mathrm{~cm}$ with electric hand shears (Accu-shears Gardena). This measurement was carried out in April, June, August, and November of each year. All samples were manually separated into clover or other grassland species, and DM was determined as described for pasture production. Annual grass and clover pasture production in each paddock was calculated from the mean annual grass and clover content of each paddock and its respective annual pasture yield.

Clover stolon and root DM mass was measured in February, March, August, and November of each year by cutting 30 random sods (each measuring $10 \times 10$ $\mathrm{cm}$ ) to a depth of approximately $8 \mathrm{~cm}$ in each paddock. Stolons with attached roots were manually separated from the sods, washed, and analyzed for DM as described above. The annual BNF was estimated from annual clover pasture yield, sward age, and soil type using the model by Høgh-Jensen et al. (2004).

\section{Animal Production Measurements}

Milk Production, Liveweight, and BCS. Cows were milked at 0730 and $1530 \mathrm{~h}$ daily throughout lactation in both years of the study. Individual cow milk yield was recorded at each milking. Milk composition from each cow was determined weekly from one successive morning and evening milking sample from each cow using a Milkoscan 203 analyzer (Foss Electric). The liveweight (LW) of cows were recorded weekly using weighing scales and the Winweigh software package (Tru-test Limited). Body condition score of each cow was recorded fortnightly using the methodology described by Edmonson et al. (1989). 
Days at Pasture and Intake Estimates. Days at pasture were recorded for each cow with a value of 1.0 ascribed to each $24 \mathrm{~h}$ period and a value of 0.5 if the animal was at pasture by day only. The amount of concentrate fed per cow was recorded at each milking (Dairymaster) and silage intake was measured as silage fed to cows when housed. Intake of grazed pasture DM by each cow was estimated as the difference between net energy ( $\mathbf{N E}$ ) provided from silage and concentrates and that needed to meet the NE requirements for milk production, maintenance, and pregnancy (Jarrige et al., 1986; Jarrige 1989; O'Mara 1996). Feed costs were based on prices at that time (Teagasc, 2013).

Milk Processability. During the second year of the study, milk samples were collected fortnightly from each system and analyzed for milk processability characteristics. Milk processability was assessed from August 1, 2009 (approximately wk 23 of lactation), until December 2, 2009 (end of lactation), for ES100N and ES0N, and from September 1, 2009 (approximately wk 23 of lactation), until 23 January 2010 (end of lactation), for LS0N. Pooled morning and evening bulk milk samples from each system were collected, stored overnight at $4^{\circ} \mathrm{C}$ and analyzed in triplicate on the following day. An aliquot of each pooled milk sample was analyzed for fat, protein and lactose concentrations using a Milkoscan 203 analyzer (Foss Electric). Somatic cell count was measured by laser-based flow cytometry (Somacount 300, Bentley Instruments Inc.). Milk samples were also analyzed for casein concentration, NPN, and total protein content. These were measured using the Kjeldahl method [methods 29 (IDF, 1964), 20-4 (ISO/IDF, 2001), and 20-3 (ISO/IDF, 2004), respectively] using a Tecator Digestor Auto and Kjeltec 8400 distiller (Foss Electric). Casein number was expressed as casein divided by total protein multiplied by 100 .

Rennet gelation characteristics were determined using low-amplitude strain oscillation (Advanced Rheometer AR550, T. A. Instruments Ltd.). The $\mathrm{pH}$ of $100 \mathrm{~mL}$ of milk was standardized to 6.55 at room temperature. The temperature of the milk was then brought to $31^{\circ} \mathrm{C}$ by immersing the milk sample in a water bath, and if required, the $\mathrm{pH}$ was readjusted to 6.55. Rennet (Chymax Plus, Pfizer Inc.), diluted to $1: 20$ with deionized water, was then added to milk at a level $0.18 \mathrm{~mL}$ of undiluted rennet/L of milk. The sample was subjected to a low-amplitude shear strain of 0.025 at a frequency of $1 \mathrm{~Hz}$ and the elastic shear modulus $\left(\mathbf{G}^{\prime}\right)$ was measured continuously as a function of time (Guinee et al., 1997). The following variables were calculated from the resultant $\mathrm{G}^{\prime}$-time profiles: gelation time $(\mathbf{G T})$, defined as the time in seconds for $\mathrm{G}^{\prime}$ to reach a value $\geq 0.2 \mathrm{~Pa}$; maximum curd firming rate $\left(\mathbf{C F R} \mathbf{R}_{\text {max }}\right)$, defined as the maximum slope of the $\mathrm{G}^{\prime}$-time curve; and gel strength defined as the $\mathrm{G}^{\prime}$ value at $50 \mathrm{~min}$ from rennet addition.

\section{Statistical Analyses}

We conducted an ANOVA with the MIXED procedure in SAS 9.3 (SAS Institute Inc.) using the following model:

$$
\begin{gathered}
X_{j k l}=\mu \\
+S_{j}+Y_{k}+M_{l}+S Y_{j k}+S M_{j l} \\
+Y M_{k l}+S T M_{j k l}+e_{j k l},
\end{gathered}
$$

where $X_{j k l}$ is the mean dependent variable, $\mu$ is overall mean, $S_{j}$ is the fixed effect of the $j$ th grazing system, $Y_{k}$ is the fixed effect of the $k$ th year, $M_{l}$ is the fixed effect of the lth sampling date and $e_{j k l}$ is residual error term. Year and sampling date were entered as repeat measures using the un@cs covariance structure as recommended by Moser (2004). Paddock was replicate for sward measurements and cow was replicate for animal measurements. Year was used as replicate for sward and animal measurements that were calculated on a herd basis for each system. Grass and clover measurements were analyzed separately using the model. The relationships between November clover stolon and root DM mass and February clover stolon and root DM mass were analyzed for effect of the system with simple linear regression using the GLM procedure in SAS.

Data were analyzed with a repeated measures linear model fitted using the MIXED procedure in SAS 9.3. Responses analyzed were GT, $\mathrm{CFR}_{\max }$, gel strength, total protein, casein, NPN, casein number, fat, protein, lactose and SCC. Mean values for main effects or interaction, as appropriate, were compared with a Tukey adjustment for multiplicity effects. Residual checks were made to ensure that the assumptions of the analyses were met.

\section{RESULTS}

\section{Meteorological Data}

Mean daily soil temperature and monthly rainfall amounts for the study period and the previous 10-yr means are shown in Figure 1. Mean soil temperature was $9.5^{\circ} \mathrm{C}$ in 2008 and $9.6^{\circ} \mathrm{C}$ in 2009 , whereas the previous 10 -yr mean was $10.9^{\circ} \mathrm{C}$ (range: $10.0-11.8^{\circ} \mathrm{C}$; Figure 1a). Total rainfall was $1,228 \mathrm{~mm}$ in 2008 and $1,296 \mathrm{~mm}$ in 2009, both of which substantially exceeded the previous 10-yr annual average of 1,004 mm (range: 797-1,150 $\mathrm{mm}$; Figure 1b). Monthly rainfall was higher particu- 

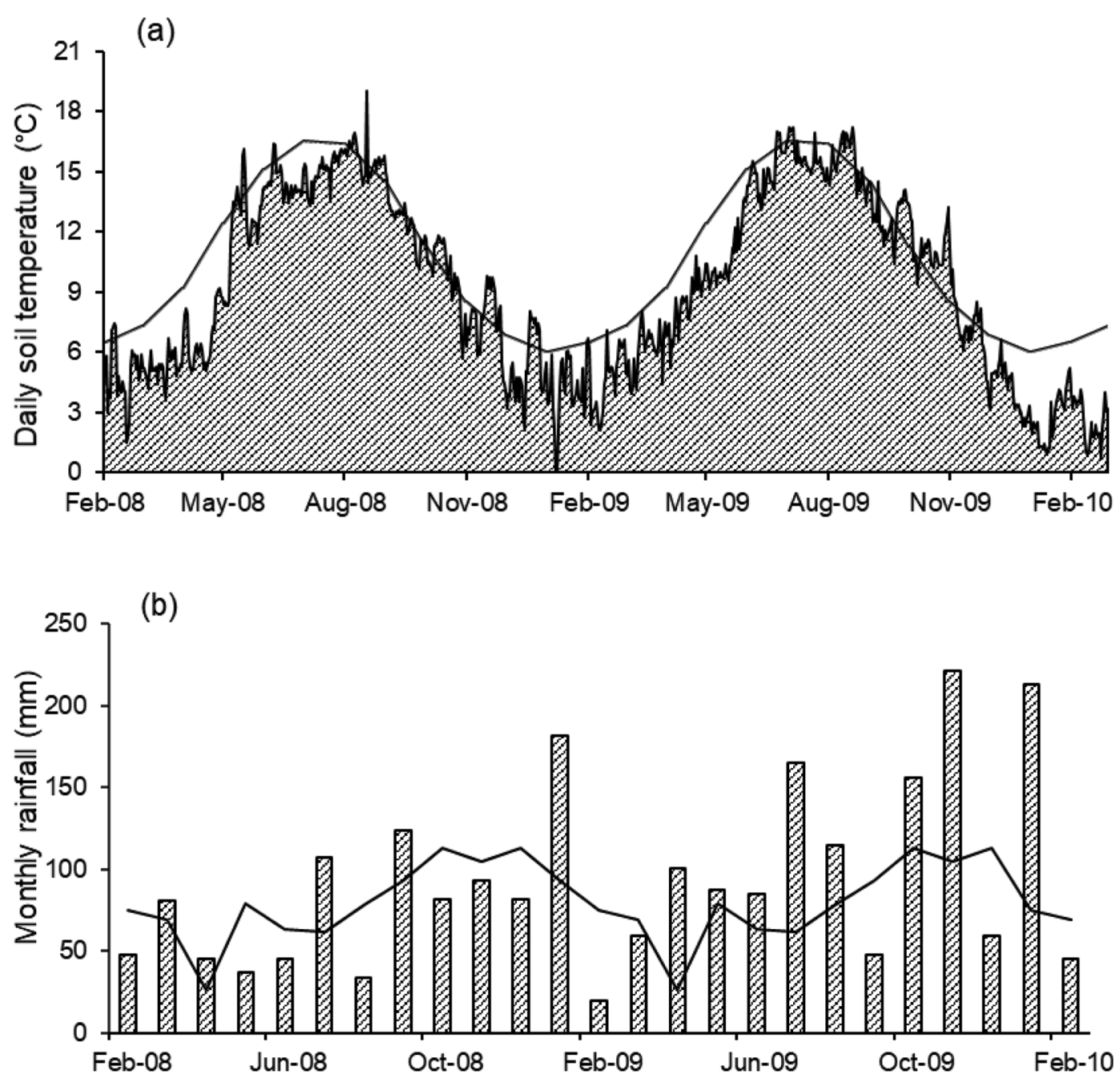

Figure 1. Mean daily soil temperature (a) and monthly rainfall (b) recorded at the meteorological station at Solohead Research Farm between February 2008 and February 2010. The shaded areas show the recorded values during the study period, and the solid lines show the previous 10 -yr mean values (1998 to 2007).

larly in the summer months of both years. Nevertheless, some months, such as February and December in both years had lower rainfall than the previous 10-yr means (Figure 1b).

\section{Pasture Production and Nutritive Value}

Averaged over both years annual pasture DM production on ES100N was similar to LS0N and was higher $(P<0.05)$ on both of these systems than ES0N (Table $2)$. Grass DM production was higher $(P<0.001)$ on ES100N than on the other systems in both years. Clover DM production was affected by an interaction between grazing system and year. There was no difference in clover DM production between systems in 2008.
Clover DM production was higher in 2009 than 2008 on the ES0N and LS0N and significantly so $(P<0.05)$ on LS0N. In 2009 LS0N had higher $(P<0.05)$ clover DM production than ES100N and was not different from ES0N. Mean postgrazing sward height was not affected by grazing system $($ mean $=4.97 \mathrm{~cm}, \mathrm{SEM}=0.042, P$ $>0.05)$.

There were no $(P>0.05)$ differences between systems in mean IVOMD (Figure 2a), CP (Figure 2b) and ash content, which averaged $102 \mathrm{~g} \cdot \mathrm{kg}^{-1}(\mathrm{SEM} \pm 8.23)$ for each system averaged over both years. There were no significant differences in composition of silage fed to cows during this study. The mean composition $( \pm \mathrm{SD})$ of silage DM was $78 \mathrm{~g} \cdot \mathrm{kg}^{-1}$ ash $( \pm 13.3), 784 \mathrm{~g} \cdot \mathrm{kg}^{-1}$ OMD $( \pm 6.3)$, and $122 \mathrm{~g} \cdot \mathrm{kg}^{-1} \mathrm{CP}( \pm 18.9)$. 


\section{Clover Content of Pasture DM, Biological Nitrogen Fixation, Stolon and Root DM Mass}

Clover content of pasture DM was affected by an interaction between grazing system, month, and year $(P$ $<0.001$; Table 3). Systems ES0N and LS0N had similar clover contents throughout 2008, whereas LS0N had higher clover content in August $2009(P<0.01$; Table $3)$. In 2008, ES100N had lower clover content than the other 2 systems in June, whereas in 2009, ES100N had lower clover contents in both June and August $(P<$ 0.01; Table 3). Biological $\mathrm{N}$ fixation was affected by an interaction between grazing system and year $(P<$ 0.01; Table 2). The mean BNF was significantly lower in ES100N than the other systems in $2009(P<0.05$; Table 2).

Clover stolon and root DM mass were affected by an interaction between grazing system and year, being similar across systems in 2008 but significantly lower in ES100N in $2009(P<0.01$; Table 3). There were positive correlations between stolon and root DM mass in November and stolon and root DM mass in the following February in both years (Figure 3). Stolon and root DM mass in February was $64 \%$ of that in the previous November on LS0N $\left(\mathrm{R}^{2}=0.84, P<0.01\right)$ and approximately $50 \%$ on ES0N $\left(\mathrm{R}^{2}=0.34, P<0.05\right)$ and ES100N $\left(\mathrm{R}^{2}=0.59, P<0.01\right)$.

\section{Days at Pasture, Feed Intake per Cow, and Silage Surpluses and Deficits}

The number of days at pasture per cow for ES100N was $(P<0.001)$ less than ES0N and LS0N (219 vs. 234 and $233 \mathrm{~d}$, respectively; Tables 1 ). On the other hand, the number of grazing days per hectare was higher with higher stocking rate (Table 1). Cows on LS0N system consumed a mean additional $136 \mathrm{~kg} \cdot \mathrm{cow}^{-1}$ of concentrates compared with ES100N and ES0N $(P<0.001)$. Intake of grazed pasture per cow was higher on ESON and silage DM intake was correspondingly lower (Table 4). Combined over 2 yr, ES100N had a silage DM deficit of $0.44 \mathrm{~kg} \cdot \mathrm{cow}^{-1}$, whereas ESON and LSON had silage surpluses of 0.09 and $1.03 \mathrm{~kg}$ of DM·cow ${ }^{-1}$, respectively.

Table 2. The effect of grazing system ${ }^{1}$ on pasture DM production and annual estimated biological nitrogen fixation $\left(\mathrm{BNF}, \mathrm{kg} \cdot \mathrm{ha}^{-1}\right)$

\begin{tabular}{|c|c|c|c|c|}
\hline \multirow[b]{2}{*}{ Variable } & \multicolumn{3}{|c|}{ Grazing system } & \multirow[b]{2}{*}{ SEM } \\
\hline & ES100N & ESON & LS0N & \\
\hline \multicolumn{5}{|c|}{ Pasture DM production $\left(\mathrm{t} \cdot \mathrm{ha}^{-1}\right)$} \\
\hline \multicolumn{5}{|l|}{2008} \\
\hline Grass & 8.22 & 6.41 & 7.11 & \\
\hline Clover & 2.13 & 2.47 & 2.07 & \\
\hline Total & 10.35 & 8.88 & 9.18 & \\
\hline \multicolumn{5}{|l|}{2009} \\
\hline Grass & 8.18 & 5.83 & 6.73 & \\
\hline Clover & 1.69 & 2.80 & 3.58 & \\
\hline Total & 9.88 & 8.63 & 10.31 & \\
\hline \multicolumn{5}{|l|}{$\mathrm{BNF}\left(\mathrm{kg} \cdot \mathrm{ha}^{-1}\right)$} \\
\hline 2008 & 113 & 131 & 110 & \\
\hline 2009 & 90 & 149 & 191 & \\
\hline \multicolumn{5}{|l|}{ System } \\
\hline Grass & & & & $0.293^{* * *}$ \\
\hline Clover & & & & $0.262^{*}$ \\
\hline Total pasture & & & & $0.389^{*}$ \\
\hline $\mathrm{BNF}$ & & & & $16.6^{*}$ \\
\hline \multicolumn{5}{|l|}{ Year } \\
\hline Grass & & & & 0.239 \\
\hline Clover & & & & 0.137 \\
\hline Total pasture & & & & 0.319 \\
\hline $\mathrm{BNF}$ & & & & $10.8^{*}$ \\
\hline \multicolumn{5}{|l|}{ System $\times$ Year } \\
\hline Grass & & & & 0.414 \\
\hline Clover & & & & $0.373^{*}$ \\
\hline Total pasture & & & & 0.553 \\
\hline $\mathrm{BNF}$ & & & & $18.8^{* *}$ \\
\hline
\end{tabular}


Milk Production, Liveweight, BCS, and Milk Processability

There was no $(P>0.05)$ difference in per-lactation milk yield $\left(6,335 \pm 119.8 \mathrm{~kg} \cdot \mathrm{cow}^{-1}\right)$, fat $(271 \pm 6.0$ $\left.\mathrm{kg} \cdot \mathrm{cow}^{-1}\right)$, protein $\left(226 \pm 4.0 \mathrm{~kg} \cdot \mathrm{cow}^{-1}\right)$, and lactose $\left(297 \pm 5.9 \mathrm{~kg} \cdot \mathrm{cow}^{-1}\right)$ yields per cow between the $3 \mathrm{graz}-$ ing systems. There was no $(P>0.05)$ difference in dairy cow LW during $(585 \pm 6.7 \mathrm{~kg})$ or at the end of lactation $(585 \pm 6.7 \mathrm{~kg})$; likewise for BCS during $(3.02 \pm 0.029)$ or at the end of lactation $(2.98 \pm 0.044)$. Somatic cell counts in late lactation were not influenced by the grazing system $(P>0.05$; Table 5$)$. The LS0N system had lower $(P<0.001)$ concentrations of fat, protein, casein and total protein between wk 23 and the end of lactation compared with ES100N and ES0N (Table 5). There
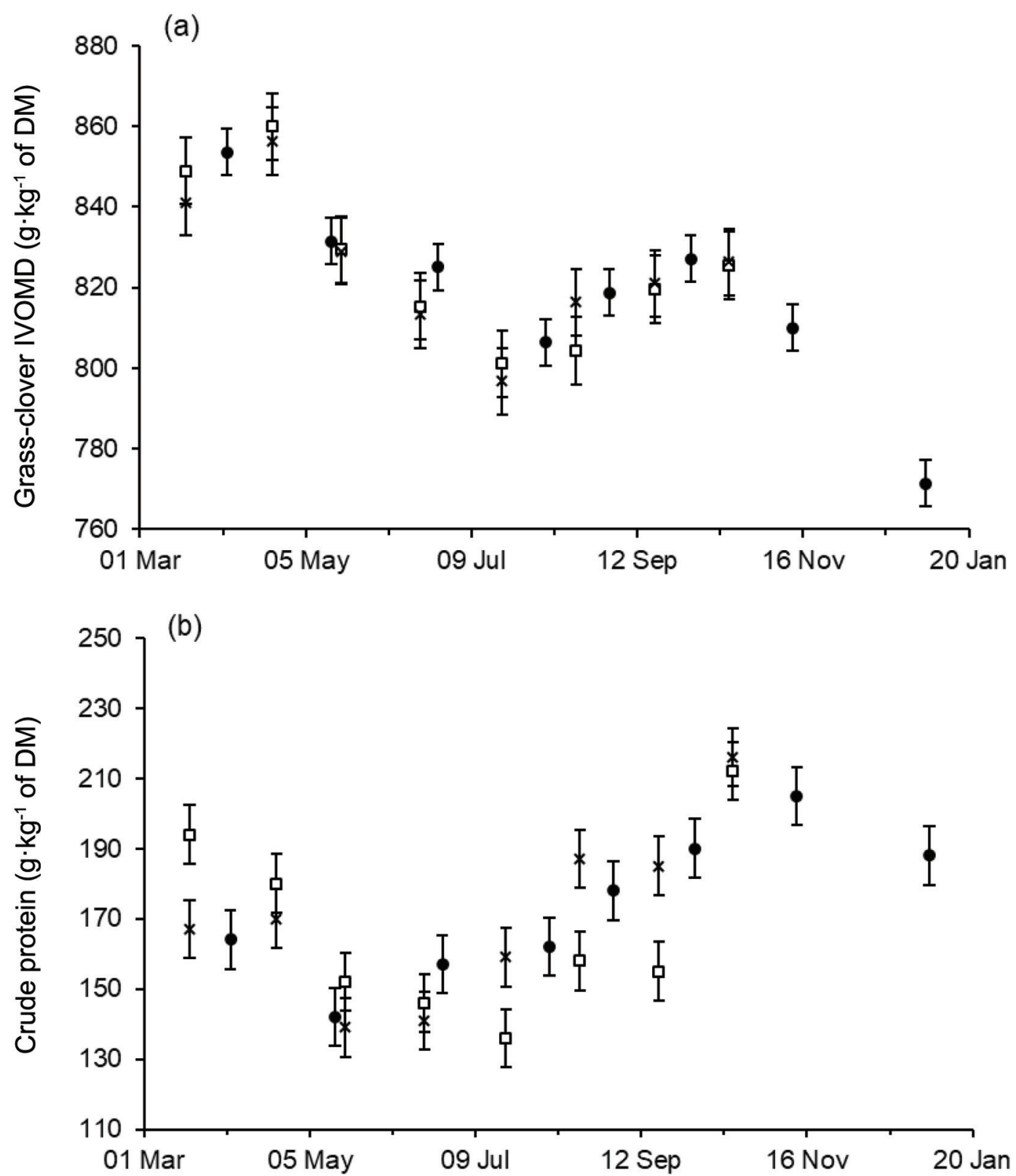

Figure 2. Effect of pasture nutritive value of grass-clover in vitro organic matter digestibility (IVOMD) (a) and crude protein (b) for each system, ES100N $(\square)$, ES0N $(x)$ and LS0N $(\bullet)$. Error bars show the SEM for the interaction between grazing rotation and system, $P>0.05$ ES100N = early spring calving with annual fertilizer N input of $100 \mathrm{~kg} \cdot \mathrm{ha}^{-1}$ applied in spring; ES0N = early spring calving without fertilizer N; LSON = late spring calving without fertilizer N. 
were no significant differences in lactose, casein number and NPN of late-lactation milk between the systems. Rheological measurements indicated that $\mathrm{CFR}_{\max }$, and GT were $(P<0.001)$ shorter for milk produced on LS0N compared with ES100N and ES0N (Table 5). Gel strength at 50 min was $(P<0.001)$ greater for ES100N and ESON than LSON (Table 5).

\section{DISCUSSION}

\section{Pasture and Milk Production}

In previous studies at this site, the average number of grazing days per year was 255 per cow (Humphreys et al., 2008, 2009). Likewise, with similar input of fertilizer

Table 3. The effect of grazing system ${ }^{1}$ on clover content of pasture DM production and mass of clover stolon and root

\begin{tabular}{|c|c|c|c|c|}
\hline \multirow[b]{2}{*}{ Variable } & \multicolumn{3}{|c|}{ Grazing system } & \multirow[b]{2}{*}{ SEM } \\
\hline & ES100N & ESON & LSON & \\
\hline \multicolumn{5}{|c|}{ Clover content of pasture DM $\left(\mathrm{g} \cdot \mathrm{kg}^{-1}\right)$} \\
\hline \multicolumn{5}{|c|}{2008} \\
\hline April & 109 & 233 & 161 & \\
\hline June & 285 & 390 & 393 & \\
\hline August & 301 & 326 & 258 & \\
\hline November & 115 & 152 & 117 & \\
\hline Mean & 203 & 275 & 232 & \\
\hline \multicolumn{5}{|l|}{2009} \\
\hline April & 58 & 62 & 119 & \\
\hline June & 165 & 322 & 294 & \\
\hline August & 321 & 421 & 557 & \\
\hline November & 112 & 161 & 156 & \\
\hline Mean & 164 & 242 & 282 & \\
\hline \multicolumn{5}{|c|}{ Clover stolon and root DM $\left(\mathrm{kg} \cdot \mathrm{ha}^{-1}\right)$} \\
\hline \multicolumn{5}{|l|}{2008} \\
\hline February & 769 & 904 & 705 & \\
\hline March & 737 & 969 & 888 & \\
\hline August & 599 & 785 & 778 & \\
\hline November & 632 & 934 & 694 & \\
\hline Mean & 684 & 898 & 766 & \\
\hline \multicolumn{5}{|l|}{2009} \\
\hline February & 339 & 527 & 608 & \\
\hline March & 344 & 710 & 797 & \\
\hline August & 581 & 807 & 1,066 & \\
\hline November & 610 & 885 & 1,052 & \\
\hline Mean & 469 & 732 & 881 & \\
\hline \multicolumn{5}{|l|}{2010} \\
\hline February & 400 & 572 & 709 & \\
\hline \multicolumn{5}{|l|}{ System } \\
\hline Clover content & & & & $25.8^{*}$ \\
\hline Stolon and root mass & & & & $43.3^{* * *}$ \\
\hline \multicolumn{5}{|l|}{ Year } \\
\hline Clover content & & & & 16.8 \\
\hline Stolon and root mass & & & & 34.8 \\
\hline \multicolumn{5}{|l|}{ Month } \\
\hline Clover content & & & & $19.9^{* * *}$ \\
\hline Stolon and root mass & & & & 50.6 \\
\hline \multicolumn{5}{|l|}{ System $\times$ Year } \\
\hline Clover content & & & & $29.1^{*}$ \\
\hline Stolon and root mass & & & & $60.3^{* *}$ \\
\hline \multicolumn{5}{|l|}{ System $\times$ Month } \\
\hline Clover content & & & & 34.5 \\
\hline Stolon and root mass & & & & 86.7 \\
\hline \multicolumn{5}{|l|}{ Year $\times$ Month } \\
\hline Clover content & & & & $23.4^{* * *}$ \\
\hline Stolon and root mass & & & & $69.6^{* *}$ \\
\hline \multicolumn{5}{|l|}{ System $\times$ Year $\times$ Month } \\
\hline Clover content & & & & $40.6^{* * *}$ \\
\hline Stolon and root mass & & & & 120.5 \\
\hline
\end{tabular}


Table 4. Effect of grazing system ${ }^{1}$ on silage DM ensiled, annual budgets of feed intake per cow with the end-of-year surpluses or deficits (negative values) per cow, purchases (negative values) and sales (positive values) of concentrate DM and silage DM per cow and per hectare over 2 yr

\begin{tabular}{|c|c|c|c|c|c|c|}
\hline \multirow[b]{2}{*}{ Item } & \multicolumn{3}{|c|}{2008} & \multicolumn{3}{|c|}{2009} \\
\hline & ES100N & ESON & LSON & ES100N & ESON & LSON \\
\hline Silage DM ensiled $^{2}$ & 0.83 & 0.96 & 1.41 & 0.71 & 1.15 & 2.12 \\
\hline \multicolumn{7}{|l|}{ Intake per $\operatorname{cow}^{3}\left(t \cdot \operatorname{cow}^{-1}\right)$} \\
\hline Grazed pasture DMI & 3.23 & 3.41 & 3.12 & 3.13 & 3.33 & 3.15 \\
\hline Concentrate DMI & 0.50 & 0.50 & 0.72 & 0.65 & 0.58 & 0.62 \\
\hline Silage DMI & 1.46 & 1.32 & 1.35 & 1.47 & 1.31 & 1.30 \\
\hline Concentrate DM & -165 & -165 & -237 & -213 & -190 & -206 \\
\hline Silage DM & -46 & -5 & 70 & -69 & 29 & 198 \\
\hline \multicolumn{7}{|l|}{ Purchases/sales of feed $\left(€ \cdot h a^{-1}\right)$} \\
\hline Concentrate DM & -347 & -264 & -363 & -448 & -304 & -315 \\
\hline Silage DM & -97 & -8 & 107 & -144 & 47 & 302 \\
\hline
\end{tabular}

${ }^{1} \mathrm{ES} 100 \mathrm{~N}$ = early spring calving with annual fertilizer $\mathrm{N}$ input of $100 \mathrm{~kg} \cdot \mathrm{ha}^{-1}$ applied in spring; ES0N = early spring calving without fertilizer $\mathrm{N} ; \mathrm{LS} 0 \mathrm{~N}=$ late spring calving without fertilizer $\mathrm{N}$.

${ }^{2}$ Proportional loss during ensilage assumed to be 0.25 (McGechan, 1989, 1990).

${ }^{3}$ Daily herbage intake at pasture, estimated from energy balances.

${ }^{4}$ Silage DM ensiled minus silage intake.

$\mathrm{N}$ to grass-clover swards and using the same methods of measuring pasture DM production, Humphreys et al. (2009) recorded a mean annual pasture DM production of $11.5 \mathrm{t} \cdot \mathrm{ha}^{-1}$ averaged over $4 \mathrm{yr}$ between 2003 and 2006. Hence the lengths of the grazing season and annual yields of pasture on ES100N (10.35 and 9.88 $\mathrm{t} \cdot \mathrm{ha}^{-1}$ ) in the present study were lower than in earlier similar studies at this site. Lower pasture production can be attributed to annual average soil temperatures in both years that were $>1.0^{\circ} \mathrm{C}$ below average and annual volumes of rainfall that were $>20 \%$ above average on this site with impeded drainage that is prone to

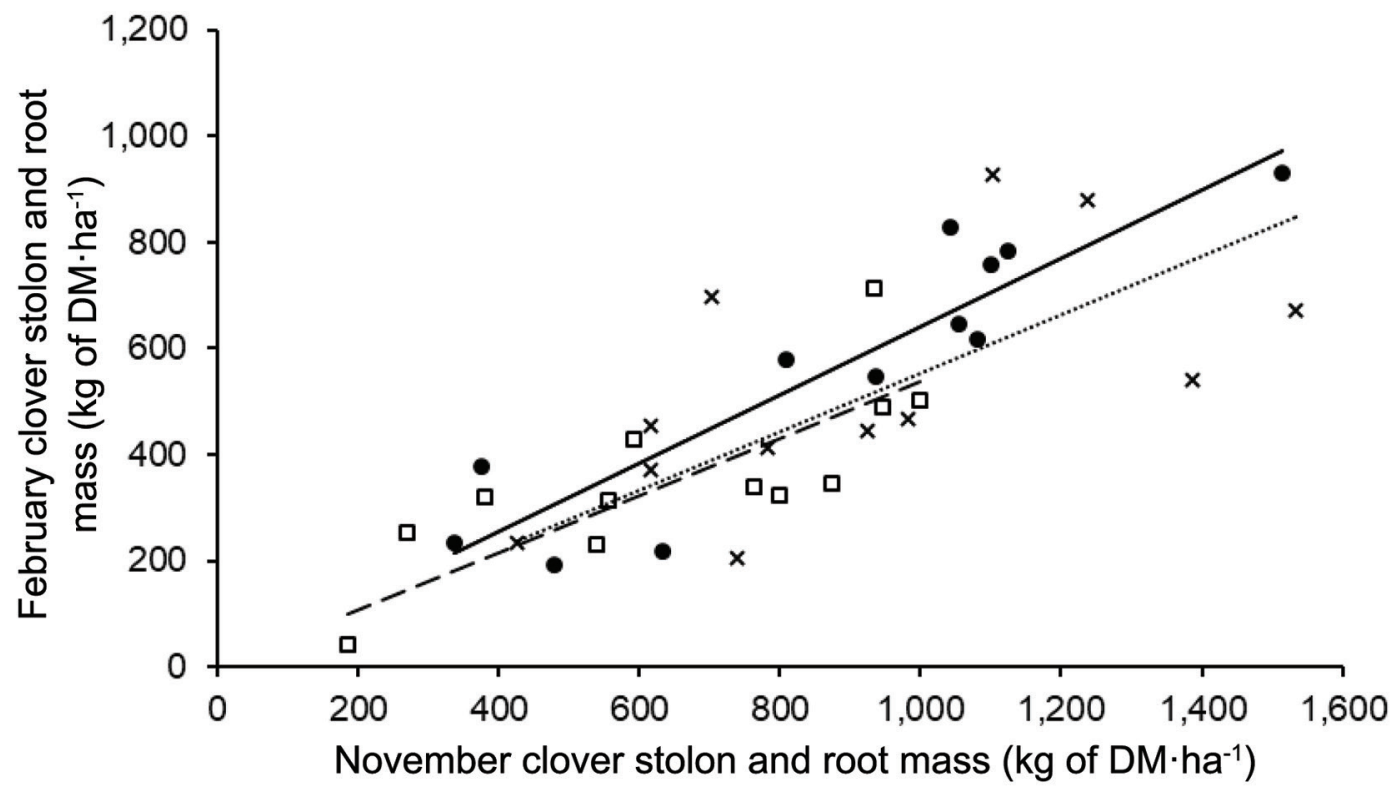

Figure 3. Relationship between clover stolon and root DM mass in November and the following February for 3 grazing systems, ES100N ( $\square$, long-dash fitted line: $\left.\mathrm{y}=0.538 \mathrm{x}, \mathrm{R}^{2}=0.59, P=0.002\right)$. ESON (x, dotted fitted line: $\left.\mathrm{y}=0.553 \mathrm{x}, \mathrm{R}^{2}=0.34, P=0.03\right)$ and LS0N $(\bullet$, solid fitted line: $\left.\mathrm{y}=0.641 \mathrm{x}, \mathrm{R}^{2}=0.84, P=0.004\right)$. Data are from both years of the study (2008-2009 and 2009-2010). ES100N = early spring calving with annual fertilizer $\mathrm{N}$ input of $100 \mathrm{~kg} \cdot \mathrm{ha}^{-1}$ applied in spring; ESON = early spring calving without fertilizer N; LS0N = late spring calving without fertilizer $\mathrm{N}$. 
Table 5. Milk composition and processing characteristics of milk from spring-calved cows in late lactation $2009-2010$ (wk 23 to end of lactation) ${ }^{1}$

\begin{tabular}{|c|c|c|c|c|c|}
\hline \multirow[b]{2}{*}{ Item $^{2}$} & \multicolumn{3}{|c|}{ System } & \multirow{2}{*}{$\begin{array}{c}\text { Pooled } \\
\text { SEM }\end{array}$} & \multirow{2}{*}{$\frac{P \text {-value }}{\text { System }}$} \\
\hline & ES100N & ES0N & LSON & & \\
\hline Fat $\left(\mathrm{g} \cdot \mathrm{kg}^{-1}\right)$ & 49.3 & 47.8 & 46.2 & 0.23 & $* * *$ \\
\hline Protein $\left(\mathrm{g} \cdot \mathrm{kg}^{-1}\right)$ & 38.2 & 38.6 & 36.7 & 0.31 & $* * *$ \\
\hline Lactose $\left(\mathrm{g} \cdot \mathrm{kg}^{-1}\right)$ & 45.1 & 45.0 & 44.7 & 0.12 & NS \\
\hline Casein $\left(\mathrm{g} \cdot \mathrm{kg}^{-1}\right)$ & 29.1 & 29.4 & 28.6 & 0.09 & *** \\
\hline Total protein $\left(\mathrm{g} \cdot \mathrm{kg}^{-1}\right)$ & 37.8 & 38.2 & 36.8 & 1.20 & $* * *$ \\
\hline Casein number $\left(\mathrm{g} \cdot \mathrm{kg}^{-1}\right)$ & 77.9 & 77.2 & 76.7 & 0.66 & NS \\
\hline $\mathrm{NPN}\left(\mathrm{g} \cdot \mathrm{kg}^{-1}\right)$ & 0.26 & 0.27 & 0.28 & 0.30 & NS \\
\hline $\mathrm{SCC}$ & 203 & 195 & 198 & 7.49 & NS \\
\hline GT $(\mathrm{s})$ & 1,243 & 1,141 & 1,106 & 3.91 & $* * *$ \\
\hline $\mathrm{CFR}_{\max }\left(\mathrm{Pa} \cdot \mathrm{min}^{-1}\right)$ & 3.41 & 3.50 & 3.22 & 0.005 & $* * *$ \\
\hline GS $(\mathrm{Pa})$ & 79.5 & 78.6 & 71.0 & 0.18 & *** \\
\hline
\end{tabular}

${ }^{1} \mathrm{ES} 100 \mathrm{~N}=$ early spring calving with annual fertilizer $\mathrm{N}$ input of $100 \mathrm{~kg} \cdot \mathrm{ha}^{-1}$ applied in spring; ES0N = early spring calving without fertilizer $\mathrm{N}$; LSON = late spring calving without fertilizer N.

${ }^{2} \mathrm{SCC}=$ somatic cell count values reported are cells $/ \mathrm{mL} \div 1,000 ; \mathrm{GT}=$ gelation time; $\mathrm{CFR}_{\max }=$ maximum curd firming rate; GS = gel strength.

${ }^{3}$ Casein number $=($ casein $\div$ total protein $) \times 100$.

$* * * P<0.001$.

waterlogging; excess rainfall lowered pasture production and caused inferior grazing conditions compared with the earlier studies. Furthermore, the stocking rate imposed on ES100N was based on previous research at this site (Humphreys et al., 2009) and during the present study required the purchase of an additional 0.45 t silage DM per cow (Table 4). Nevertheless, taking into account the adverse weather conditions during the present study, the stocking rate and feed demand on ES100N was reasonably well aligned with the pasture production potential at this site.

The 2 zero-fertilizer $\mathrm{N}$ input systems had lower milk output per hectare than ES100N. However, milk output per hectare was constrained by the stocking rates of dairy cows imposed on systems in this study. In contrast to ES100N there was a surplus of silage generated on both zero-fertilizer $\mathrm{N}$ systems averaged over both years, which indicates that stocking rates on both of these systems were suboptimal to fully utilize available pasture, particularly LSON. Averaged over both years annual pasture DM production on ES100N was similar to LS0N and certainly in 2009 LS0N produced sufficient pasture to carry a similar stocking rate of dairy cows to ES100N.

\section{Milk Production per Cow}

There were no significant differences in annual milk production and milk composition per cow between the 3 grazing systems in the current study. Similarly, Glassey et al. (2013) reported no difference in annual milk production per cow by cows grazing grass-clover swards receiving and not receiving input of fertilizer
N. The IVOMD and CP of grazed swards did not differ between the systems, which partly accounts for the absence of a difference in dairy cow performance in the present study. A recent meta-analysis (Dineen et al., 2018) found that a mean sward white clover content of approximately $320 \mathrm{~g} \cdot \mathrm{kg}^{-1}$ is required to increase in daily milk and milk solid yields per cow. The annual white clover content (range: $164-282 \mathrm{~g} \cdot \mathrm{kg}^{-1}$; Table 3) across all systems in the present study was below the level required for higher milk production per cow.

\section{Clover Production and Biological Nitrogen Fixation}

In the former study (Humphreys et al., 2009) clover content of pasture DM averaged $219 \mathrm{~g} \cdot \mathrm{kg}^{-1}$ (range: 203-239 $\mathrm{g} \cdot \mathrm{kg}^{-1} \mathrm{DM}$ ) and annual clover DM production averaged $2.52 \mathrm{t} \cdot \mathrm{ha}^{-1}$ (range: $2.10-2.85 \mathrm{t} \cdot \mathrm{ha}^{-1}$ ) averaged over the 4 years in a system with similar stocking rates and fertilizer $\mathrm{N}$ input to ES100N. The annual clover contents of pasture DM on ES100N in the present study (164 and $203 \mathrm{~g} \cdot \mathrm{kg}^{-1}$; Table 3) were lower than the former study. Likewise, the annual yields of clover pasture DM in the present study (range: 1.69 to $2.13 \mathrm{t} \cdot \mathrm{ha}^{-1}$; Table 2) were lower than the previous study, partly due to lower clover content of pasture DM and partly due to lower annual pasture DM production. It seems that the adverse weather conditions experienced during the present study lowered the clover DM production proportionally more than overall pasture DM production on ES100N.

The absence of fertilizer $\mathrm{N}$ input increased clover DM production on ES0N from $2.47 \mathrm{t} \cdot \mathrm{ha}^{-1}$ in 2008 to 2.80 t.ha ${ }^{-1}$ in 2009 (Table 2). Likewise, clover DM produc- 
tion on LS0N increased from $2.07 \mathrm{t} \cdot \mathrm{ha}^{-1}$ in 2008 to $3.58 \mathrm{t} \cdot \mathrm{ha}^{-1}$ in 2009 . Early spring has previously been identified as the optimal time to apply fertilizer $\mathrm{N}$ to grass-clover swards (Laidlaw, 1980; Harris and Clark, 1996; Humphreys et al., 2008). Little or no BNF takes place and clover growth rates are low at this time of year (Davies, 2001). Fertilizer N applied to ES100N and higher recycling of $\mathrm{N}$ in excreta increased spring and annual pasture production compared with ESON. Higher grass production following the application of fertilizer $\mathrm{N}$ was associated with lower clover DM production on ES100N in 2009, which can be attributed to greater competition from the grass component of the sward. It is well established that there is a negative relationship between $\mathrm{N}$ fertilization and the clover content of swards and hence, BNF (Laidlaw et al., 1992; Harris and Clark, 1996; Burchill et al., 2014). On the other hand, grazing during the first half of the winter (December 2008 and January 2009) combined with no fertilizer $\mathrm{N}$ input substantially increased clover DM production on LS0N in 2009 compared with ES0N. The higher pasture production on LS0N in 2009 can be attributed to higher annual clover DM production along with higher BNF.

It is apparent that the higher clover DM production and BNF on LSON in 2009 was influenced by a carryover effect from the previous year. The mass of stolon surviving over the winter is an important indicator of clover persistence (Frame and Newbould, 1986; Collins et al., 1991; Wachendorf et al., 2001). The LS0N system had higher stolon masses than the other systems in February 2009 and February 2010. There was a net loss of stolon mass of $22 \%$ between November 2008 and February 2009 on LS0N compared with $55 \%$ on the 2 early spring grazing systems, which had an earlier closing date (Table 1). As a consequence of this, LS0N had higher stolon mass throughout 2009. The net loss of stolon over the winter 2009-10 was similar in the 3 systems (approximately 34\%). Nevertheless, the LS0N had higher stolon mass than the other systems at the end of the study in February 2010 as a consequence of having higher stolon mass during the 2009 growing season.

It seems that grazing during the winter by the cows on LS0N favored clover stolon survival, perhaps by allowing greater light penetration to the base of the sward during the winter (Phelan et al., 2014). A similar result was found in Northern Ireland by Laidlaw and Stewart (1987) and Laidlaw et al. (1992), who found that grazing by sheep over the winter improved clover content of pasture DM in the following spring relative to no grazing between November and March. The beneficial effect on clover was attributed to lower competition from the accompanying grass. On the other hand, in Switzerland, Lüscher et al. (2001) found that frequent defoliation (7 times between November and March) caused a net loss in clover stolon DM mass by the spring. The differences in responses in the latter study and those conducted on the island of Ireland could be attributed to climatic differences between Ireland (relatively mild weather during the winter) and Switzerland and perhaps to the much greater severity of the defoliation treatments in the latter study.

\section{Milk Constituents and Processing Characteristics}

The measurements of the processability of latelactation milk indicated that there were no detectable differences in lactose, casein number, or NPN between the 3 systems. Somatic cell count was not influenced by grazing systems; mean SCC values were within the range of normality $\left(<200 \times 10^{3}\right.$ cells $\left.\cdot \mathrm{mL}^{-1}\right)$ previously reported by O'Brien et al. (2006) and Guinee and O'Brien (2010). The decrease in milk volume with the later stages of lactation coincided with increases in total protein and fat levels, and a reduction in that of lactose similar to that reported by Guinee et al. (2007). However, the late-lactation milk of the LS0N system had lower concentrations of fat, protein, casein, and total protein relative to ES100N and ES0N. While LS0N had lowest mean concentrations of milk composition and nitrogen fractions, these results were still within the range of values reported previously for spring-calved herds (Mehra et al., 1999; O'Brien et al., 1999).

The current study found that LSON had shorter coagulation times and weaker gel structures. The low firmness of LS0N gels made from late-lactation milk may be due to proteolysis of casein by plasmin (Lucey, 1996). The higher casein content of milk is expected to enhance coagulation properties with higher cheese yields (Guinee et al., 2006). In contrast to previous studies, the current study found that GT was longer for ES100N and ES0N milk (Guinee et al., 1997; Auldist et al., 2010). However, the higher protein content in the late-lactation milk from the latter systems formed a firmer gel than LS0N, which was influenced by higher concentrations of protein in the milk (Guinee et al., 1997). Guinee et al. (2006) found that during cheesemaking where curds are cut based on time, an increase in milk protein content is likely to coincide with an increase in the moisture content of the curd, because the stiffer gel at cutting has a lower ability to rearrange and lower rate of syneresis. Consequently, both ES100N and ESON potentially would have higher cheese yield. Cheddar cheese yield increases by approximately 0.25 to $0.30 \mathrm{~kg} / 100 \mathrm{~kg}$ of milk for every $0.1 \mathrm{~g} / 100 \mathrm{~g}$ in- 
crease in milk protein in the range 3.0 to $4.5 \mathrm{~g} / 100 \mathrm{~g}$, while retaining the protein-to-fat ratio constant at 0.96 (Guinee et al., 2006).

\section{Calving Date and Grazing Season Timeframe}

A key component of seasonal pasture-based milk production is achieving good synchronicity between calving date and the demand of the lactating herd for pasture and the commencement of pasture growth in spring. Whereas grazing during the winter in LSON promoted $\mathrm{BNF}$ and pasture production in the following year in the present study, the later calving strategy resulted in less pasture consumed per cow and higher supplementation with concentrates compared with ES0N (Table 4). These concentrates were mostly fed during the winter. Furthermore, on LS0N there was an excessive supply of pasture available when lactating cows were turned out to pasture in mid-April, making it necessary to close some of the area available for grazing for silage in April (Table 1). Hence, there was poor synchronicity between the herd demand for pasture and pasture availability, resulting in a less efficient and higher cost system. Furthermore, extending lactation into the early winter lowered the quality of late-lactation milk for processing purposes.

In terms of producing low-cost milk for processing into long shelf-life products, the ESON was more efficient than LS0N. Under such circumstances it is advisable that calving date is not changed from mid-February, even under zero-fertilizer $\mathrm{N}$ input. It's possible that the beneficial effects of winter grazing on subsequent clover productivity could be achieved on an ESON-type system by grazing later and to a lower PGH before housing for the winter, rather than delaying calving date. Such an approach warrants further investigation. The economic feasibility of the LSON approach depends on the purpose for which the milk is used, such as liquid milk and short shelf-life products, and any additional price paid to promote the production of this milk during the winter months.

\section{CONCLUSIONS}

The zero-fertilizer $\mathrm{N}$ input systems had lower milk production per ha than ES100N because milk output was constrained by stocking rate. Pasture production on LS0N in 2009 had the potential to carry a similar stocking rate of dairy cows to that of ES100N. Delaying calving date until mid-April on LSON resulted in inefficient use of pasture for milk production. Extending lactation into early winter lowered the quality of late-lactation milk for processing purposes. It is rec- ommended that a mean calving date in mid-February under zero-fertilizer $\mathrm{N}$ input is a better option than a later calving date. It is possible that the beneficial effects of winter grazing on clover productivity could be achieved by grazing later and to a lower post-grazing height before housing for the winter. Such an approach could carry a higher stocking rate of dairy cows under zero-fertilizer $\mathrm{N}$ input; perhaps in the region of 2.0 to 2.5 cows ha ${ }^{-1}$.

\section{ACKNOWLEDGMENTS}

The authors acknowledge the technical input of the farm staff at Teagasc Solohead Research Farm and the laboratory staff at Teagasc Moorepark. Also, thanks to Jim Grant (Statistical Support Unit, Teagasc) for his statistical guidance, advice, and help through the study. Funding for this study was provided by the Department of Agriculture, Food and the Marine via the Research Stimulus Fund (RSF 07-511). Financial support for Walsh Scholarship provided by the Interreg Atlantic Area Dairy-4-Future project (EAPA_304/2016) is gratefully acknowledged. The authors have not stated any conflicts of interest.

\section{REFERENCES}

Auldist, M. J., C. Grainger, A. V. Houlihan, J. J. Mayes, and R. P. W. Williams. 2010. Composition, coagulation properties, and cheesemaking potential of milk from cows undergoing extended lactations in a pasture-based dairying system. J. Dairy Sci. 93:14011411. https://doi.org/10.3168/jds.2009-2727.

Burchill, W., E. K. James, D. Li, G. J. Lanigan, M. Williams, P. P. M. Iannetta, and J. Humphreys. 2014. Comparisons of biological nitrogen fixation in association with white clover (Trifolium repens L.) under four fertiliser nitrogen inputs as measured using two ${ }^{15} \mathrm{~N}$ techniques. Plant Soil 385:287-302. https://doi.org/10.1007/ s11104-014-2199-1.

Chapman, D. F., J. M. Lee, L. Rossi, G. R. Edwards, J. B. Pinxterhuis, and E. M. K. Minnee. 2017. White clover: The forgotten component of high-producing pastures? Anim. Prod. Sci. 57:12691276. https://doi.org/10.1071/AN16453.

Collins, R. P., M. J. Glendining, and I. Rhodes. 1991. The relationships between stolon characteristics, winter survival and annual yields in white clover (Trifolium repens L.). Grass Forage Sci. 46:51-61. https://doi.org/10.1111/j.1365-2494.1991.tb02207.x.

Culleton, N., and R. Fox. 2001. Preliminary report on organic dairy farming. Proceedings of the Spring Scientific Meeting of the Fertilizer Association of Ireland. Fertilizer Association of Ireland.

Davies, A. 1992. White clover. Biologist 39:129-133.

Davies, A. 2001. Competition between grasses and legumes in established pastures. Pages 63-83 in Competition and Succession in Pastures. P. G. Tow and A. Lazenby, ed. CABI.

Dineen, M., L. Delaby, T. Gilliland, and B. McCarthy. 2018. Metaanalysis of the effect of white clover inclusion in perennial ryegrass swards on milk production. J. Dairy Sci. 101:1804-1816. https:// doi.org/10.3168/jds.2017-12586.

EC (European Commission). 2019. The European Green Deal. Communication from the Commission to the European Parliament, the European Council, the European Economic and Social Committee and the Committee of the Regions. Accessed Feb. 3, 2021. https:// 
eur-lex.europa.eu/legal-content/EN/TXT/HTML/?uri=CELEX: 52019 DC0640\&from $=\mathrm{EN}$.

ECE (Economic Commission for Europe). 2020. Draft Guidance document on integrated sustainable nitrogen management. United Nations Economic and Social Council. Accessed Feb. 23, 2021. http: //staging2.unece.org.net4all.ch/fileadmin/DAM/env/documents/ 2020/AIR/EB/ECE_EB.AIR_2020_6-2008239E.pdf.

Edmonson, A. J., I. J. Lean, L. D. Weaver, T. Farver, and G. Webster. 1989. A body condition scoring chart for Holstein dairy cows. J. Dairy Sci. 72:68-78. https://doi.org/10.3168/jds.S0022 -0302(89)79081-0.

Enriquez-Hidalgo, D., T. J. Gilliland, M. Egan, and D. Hennessy. 2018. Production and quality benefits of white clover inclusion into ryegrass swards at different nitrogen fertilizer rates. J. Agric. Sci. 156:378-386. https://doi.org/10.1017/S0021859618000370.

Finneran, E., P. Crosson, P. O'Kiely, L. Shalloo, D. Forristal, and M. Wallace. 2012. Stochastic simulation of the cost of home-produced feeds for ruminant livestock systems. J. Agric. Sci. 150:123-139. https://doi.org/10.1017/S002185961100061X.

Fox, P. F., T. P. Guinee, T. M. Cogan, and P. L. H. McSweeney. 2017. Factors that affect cheese quality. Pages 533-542 in Fundamentals of Cheese Science. 2nd ed. Springer. https://doi.org/http://dx.doi .org/10.1007/978-1-4899-7681-9.

Frame, J., and P. Newbould. 1986. Agronomy of White Clover. Adv. Agron. 40:1-88. https://doi.org/10.1016/S0065-2113(08)60280-1.

Glassey, C. B., C. G. Roach, J. M. Lee, and D. A. Clark. 2013. The impact of farming without nitrogen fertiliser for ten years on pasture yield and composition, milksolids production and profitability; a research farmlet comparison. Proc. N. Z. Grassland Assoc. 75:71-78. https://doi.org/10.33584/jnzg.2013.75.2925.

Guinee, T. P., C. B. Gorry, D. J. O'Callaghan, B. T. O'Kennedy, N. O'Brie, and M. A. Fenelon. 1997. The effects of composition and some processing treatments on the rennet coagulation properties of milk. Int. J. Dairy Technol. 50:99-106. https://doi.org/10.1111/ j.1471-0307.1997.tb01747.x.

Guinee, T. P., and B. O'Brien. 2010. The quality of milk for cheese manufacture. Pages 1-67 in Technology of Cheesemaking. 2nd ed. B. A. Law and A. Y. Tamime, ed. Blackwell Publishing Ltd. https: //doi.org/10.1002/9781444323740.ch1.

Guinee, T. P., B. O'Brien, and E. O. Mulholland. 2007. The suitability of milk from a spring-calved dairy herd during the transition from normal to very late lactation for the manufacture of low-moisture Mozzarella cheese. Int. Dairy J. 17:133-142. https://doi.org/10 .1016/j.idairyj.2006.02.002.

Guinee, T. P., B. T. O'Kennedy, and P. M. Kelly. 2006. Effect of milk protein standardization using different methods on the composition and yields of Cheddar cheese. J. Dairy Sci. 89:468-482. https: //doi.org/10.3168/jds.S0022-0302(06)72110-5.

Hanrahan, L., N. McHugh, T. Hennessy, B. Moran, R. Kearney, M Wallace, and L. Shalloo. 2018. Factors associated with profitability in pasture-based systems of milk production. J. Dairy Sci. 101:5474-5485. https://doi.org/10.3168/jds.2017-13223.

Harris, S. L., and D. A. Clark. 1996. Effect of high rates of nitrogen fertiliser on white clover growth, morphology, and nitrogen fixation activity in grazed dairy pasture in northern New Zealand. N. Z. J. Agric. Res. 39:149-158. https://doi.org/10.1080/00288233 .1996 .9513173 .

Høgh-Jensen, H., R. Loges, F. V. Jørgensen, F. P. Vinther, and E. S. Jensen. 2004. An empirical model for quantification of symbiotic nitrogen fixation in grass-clover mixtures. Agric. Syst. 82:181-194. https://doi.org/10.1016/j.agsy.2003.12.003.

Humphreys, J., I. A. Casey, and A. S. Laidlaw. 2009. Comparison of milk production from clover-based and fertilizer-N-based grassland on a clay-loam soil under moist temperate climatic conditions. Ir. J. Agric. Food Res. 48:71-89.

Humphreys, J., K. O'Connell, and I. A. Casey. 2008. Nitrogen flows and balances in four grassland-based systems of dairy production on a clay-loam soil in a moist temperate climate. Grass Forage Sci. 63:467-480. https://doi.org/10.1111/j.1365-2494.2008.00660.x.
Humphreys, J., P. Phelan, D. Li, W. Burchill, J. Eriksen, I. A. Casey, D. Enriquez-Hidalgo, and K. Søegaard. 2017. White clover supported pasture-based systems in north-west Europe. Pages 139156 in Legumes in Cropping Systems. CAB Int.

Hurtado-Uria, C., D. Hennessy, L. Shalloo, D. O' Connor, and L. Delaby. 2013. Relationships between meteorological data and grass growth over time in the south of Ireland. Ir. Geogr. 46:175-201. https://doi.org/10.1080/00750778.2013.865364.

IDF (International Dairy Federation). 1964. Milk-Determination of the casein content of milk description/principle: Titrimetric, Kjeldahl in casein-free filtrate and in milk. IDF 29:1964 (International Dairy Federation, Brussels, Belgium.).

ISO/IDF. 2001. Milk-Determination of nitrogen content. Part 4: Determination of non-protein-nitrogen content. International Standard ISO 8968-4:2001 (IDF 20-4:2001). International Organisation for Standardization.

ISO/IDF. 2004. Milk-Determination of nitrogen content. Part 3: Block-digestion method (Semi-micro rapid routine method). International Standard ISO 8968-3:2004 (IDF 20-3:2004). International Organisation for Standardization.

Jarrige, R. 1989. Ruminant Nutrition: Recommended Allowances and Feed Tables. John Libbey Eurotext.

Jarrige, R., C. Demarquilly, J. P. Dulphy, A. Hoden, J. Robelin, C. Beranger, Y. Geay, M. Journet, C. Malterre, D. Micol, and M. Petit. 1986. The INRA "fill unit" system for predicting the voluntary intake of forage-based diets in ruminants: A review. J. Anim. Sci. 63:1737-1758. https://doi.org/10.2527/jas1986.6361737x.

Laidlaw, A. S. 1980. The effects of nitrogen fertilizer applied in spring on swards of ryegrass sown with four cultivars of white clover. Grass Forage Sci. 35:295-299. https://doi.org/10.1111/j.1365-2494 1980.tb01526.x.

Laidlaw, A. S., and T. Stewart. 1987. Clover development in the sixth to ninth year of a grass/clover sward as affected by out-of-season management and spring fertilizer nitrogen application. Res. Dev. Agric. 4:155-160.

Laidlaw, A. S., N. Teuber, and J. Withers. 1992. Out-of-season management of grass/clover swards to manipulate clover content. Grass Forage Sci. 47:220-229. https://doi.org/10.1111/j.1365-2494 .1992.tb02266.x.

Läpple, D., T. Hennessy, and M. O'Donovan. 2012. Extended grazing: A detailed analysis of Irish dairy farms. J. Dairy Sci. 95:188-195. https://doi.org/10.3168/jds.2011-4512.

Li, D., G. Lanigan, and J. Humphreys. 2011. Measured and simulated nitrous oxide emissions from ryegrass- and ryegrass/white clover-based grasslands in a moist temperate climate. PLoS One 6:e26176. https://doi.org/10.1371/journal.pone.0026176.

Lucey, J. 1996. Cheesemaking from grass based seasonal milk and problems associated with late-lactation milk. Int. J. Dairy Technol. 49:59-64. https://doi.org/10.1111/j.1471-0307.1996.tb02491 .x.

Lüscher, A., B. Stäheli, R. Braun, and J. Nösberger. 2001. Leaf area, competition with grass, and clover cultivar: Key factors to successful overwintering and fast regrowth of white clover (Trifolium repens L.) in spring. Ann. Bot. 88:725-735.

McGechan, M. 1989. A review of losses arising during conservation of grass forage: Part 1. Field losses. J. Agric. Eng. Res. 44:1-21. https://doi.org/10.1016/S0021-8634(89)80067-8.

McGechan, M. 1990. A review of losses arising during conservation of grass forage: Part 2. Storage losses. J. Agric. Eng. Res. 45:1-30. https://doi.org/10.1016/S0021-8634(05)80135-0.

Mehra, R., B. O'Brien, J. Connolly, and D. Harrington. 1999. Seasonal variation in the composition of Irish manufacturing and retail milks: 2. Nitrogen fractions. Ir. J. Agric. Food Res. 38:65-74.

Morgan, D. J., G. Stakellum, and J. O'Dwyer. 1989. Modified neutraldetergent cellulose digestibility procedure for use with the "Fibertec" system. Isr. J. Agric. Res. 28:91-92.

Moser, E. B. 2004. Repeated measures modelling with proc mixed. Pages 1-19 in SAS Users Group International Conference 29. Vol. Paper 188.29. Montréal, Canada. SAS Institute Inc. 
O'Brien, B., T. P. Guinee, A. Kelly, and P. Joyce. 2006. Processability of late lactation milk from a spring-calved herd. Aust. J. Dairy Technol. 61:3-7.

O'Brien, B., R. Mehra, J. F. Connolly, and D. Harrington. 1999. Seasonal variation in the composition of Irish manufacturing and retail milks. 1. Chemical composition and renneting properties. Ir. J. Agric. Food Res. 38:53-64

O'Mara, F. 1996. A Net Energy System for Cattle and Sheep. Department of Animal Science, Faculty of Agriculture, University College Dublin, Belfield, Dublin, Ireland.

Phelan, P., I. A. Casey, and J. Humphreys. 2014. The effects of simulated summer-to-winter grazing management on herbage production in a grass-clover sward. Grass Forage Sci. 69:251-265. https:/ /doi.org/10.1111/gfs.12041.

SAS. 2011. SAS version 9.3. Cary, North Carolina: SAS Institute Inc. Teagasc. 2013. Teagasc Management Data for Farm Planning. Teagasc.

Wachendorf, M., R. Collins, A. Elgersma, M. Fothergill, B. FrankowLindberg, A. Ghesquiere, A. Guckert, M. Guinchard, A. Helgadottir, A. Lüscher, T. Nolan, P. Nykänen-Kurki, J. Nösberger, G.
Parente, S. Puzio, I. Rhodes, C. Robin, A. Ryan, B. Stäheli, S. Stoffel, F. Taube, and J. Connolly. 2001. Overwintering and growing season dynamics of Trifolium repens $\mathrm{L}$. in mixture with Lolium perenne L.: A model approach to plant-environment interactions. Ann. Bot. 88(Suppl. 1):683-702. https://doi.org/10.1093/annbot/ 88.suppl_1.683.

Yan, M.-J., J. Humphreys, and N. M. Holden. 2013. The carbon footprint of pasture-based milk production: Can white clover make a difference? J. Dairy Sci. 96:857-865. https://doi.org/10.3168/jds .2012-5904.

\section{ORCIDS}

K. M. Scully @ https://orcid.org/0000-0003-3881-1493

B. Keogh (1) https://orcid.org/0000-0002-0703-7784

B. O' Brien (ㅇ https://orcid.org/0000-0001-7821-0911

I. A. Casey @ https://orcid.org/0000-0002-6084-4972 